\begin{tabular}{|l|l|l||}
\hline \multicolumn{2}{|c|}{ PublisherInfo } \\
\hline \hline PublisherName & $:$ & BioMed Central \\
\hline \hline PublisherLocation & $:$ & London \\
\hline \hline PublisherImprintName & $:$ & BioMed Central \\
\hline \hline
\end{tabular}

\title{
A protein kinase switch
}

\begin{tabular}{||l|l|l||}
\hline \multicolumn{2}{|c|}{ ArticleInfo } \\
\hline \hline ArticleID & $:$ & 3782 \\
\hline \hline ArticleDOI & $:$ & $10.1186 /$ gb-spotlight-20000929-01 \\
\hline \hline ArticleCitationID & $:$ & spotlight-20000929-01 \\
\hline \hline ArticleSequenceNumber & $:$ & 219 \\
\hline \hline ArticleCategory & $:$ & Research news \\
\hline \hline ArticleFirstPage & $:$ & 1 \\
\hline \hline ArticleLastPage & $:$ & 2 \\
\hline \hline & & RegistrationDate : 2000-09-29 \\
ArticleHistory & $:$ & OnlineDate $\quad$ 2000-09-29 \\
\hline \hline ArticleCopyright & $:$ & BioMed Central Ltd2000 \\
\hline \hline ArticleGrants & $:$ & \\
\hline \hline ArticleContext & $:$ & 130591111 \\
\hline \hline
\end{tabular}




\section{William Wells}

Email: wells@biotext.com

Kinase inhibitors are plagued by a lack of specificity. Now in the 21 September Nature Bishop et al. tackle the problem by building on their earlier work, in which they modified the ATP-binding sites of Src-family tyrosine kinases to accept either nucleotide analogs or modified kinase inhibitors. In the new work the researchers mutate kinases from four distinct kinase families by replacing a bulky residue with a small residue. This change provides enough room for the binding of inhibitor analogs, which are larger than their parent inhibitors and thus do not inhibit wild-type kinases (Nature 2000, 407:395-401). The in vivo specificity is demonstrated using expression arrays. Most kinases contain a bulky residue analogous to the one mutated in this study, and thus should be amenable to the kinase-sensitization strategy.

\section{References}

1. Exploiting chemical libraries, structure, and genomics in the search for kinase inhibitors.

2. Nature, [http://www.nature.com/nature/]

3. Engineering Src family protein kinases with unnatural nucleotide specificity. 